assembly, which is given is antisocial, but contains no signs of administrative or criminal offenses.

It is argued that the subjects of the lawmaking and law-making initiative should in the near future develop normative acts that will determine the powers of the bodies of the National Police of Ukraine aimed at ensuring the exercise of the right to freedom of peaceful assembly, preventing unjustified and unlawful restrictions on the exercise of this right, and guaranteeing the protection of individual and social interests in the exercise by individual subjects of their right to freedom of peaceful assembly.

Key words: the right to freedom of peaceful assembly, powers of the National Police of Ukraine.

DOI: $10.33766 / 2524-0323.88 .147-157$

УДК 343.98

О. С. Соколов,

завідувач відділу досліджень зброї лабораторії досліджень, сертифікації зброї та обліку

Державного науково-дослідного експертно-криміналістичного центру МВС України

(м. Київ, Україна)

e-mail: ballistekc@gmail.com

iD https://orcid.org/0000-0001-7613-1590

\title{
ПЕРСПЕКТИВИ РЕФОРМУВАННЯ УКРАЇНСЬКОГО ЗАКОНОДАВСТВА У СФЕРІ ОБІГУ ЗБРОЇ З УРАХУВАННЯМ ПОЛОЖЕНЬ СВРОПЕЙСЬКИХ ПРАВОВИХ АКТІВ
}

Ураховуючи положення Конституції України щодо стратегічного курсу держави на набуття повноправного членства в Свропейському Союзі, у статті розглянуто основні положення директив, регламентів та інших правових актів Свропейського Союзу, які стосуються сфери контролю над легким озброєнням і стрілецькою зброєю, а також проведено їх порівняльний аналіз з положеннями існуючих національних нормативноправових актів, що регулюють сферу обігу цивільної зброї в Україні. Розглянуто основні вимоги європейського законодавства щодо контролю за обігом зброї, які $є$ обов'язковими для імплементації в національне законодавство країн-членів та країнкандидатів на вступ до Європейського Союзу. Проведено порівняльний аналіз положень українського та європейського законодавств, які стосуються категорій забороненої зброї та зброї, цивільний обіг якої $є$ обмеженим. Розглянуто основні положення законодавчих ініціатив Верховної Ради України, направлених на правове врегулювання обігу зброї в Україні та проведено порівняння їх основних положень із положеннями правових актів Свропейського Союзу. Запропоновано найкращі рішення щодо гармонізації українського національного законодавства у сфері контролю над стрілецькою зброєю та легким озброєнням відповідно до права Європейського Союзу.

Ключові слова: Директива ЄС, Регламент СС, імплементація, категорії зброї, гармонізація законодавства.

Постановка проблеми. Конституцією України закріплений стратегічний курс держави на набуття повноправного членства в Свропейському Союзі (далі - СС). 3 метою реалізації зазначеного курсу, Верховною Радою України

(С) Соколов О. С., 2019 
затверджено Загальнодержавну програму адаптації законодавства України до законодавства СС, яка містить положення, необхідні для досягнення відповідності правової системи України (acquis communautaire), з урахуванням критеріїв, що висуваються СС, до держав, які мають намір вступити до нього.

Правове регулювання обігу зброї в СС здійснюється такими документами:

- Директива 91/477СЕС щодо контролю за придбанням зброї і володінням зброєю (змінена директивами Свропарламенту та Ради ЄС 2008/51/ЄС від 21 травня 2008 року та 2017/852 від 17.05.2017);

- Регламент Комісії СС 2015/2403 від 15 грудня 2015 року щодо встановлення загальних вказівок щодо стандартів та методів деактивації для забезпечення незворотності повторної активації вогнепальної зброї;

- Директива 2019/68 від 16 січня 2019 року щодо встановлення технічних специфікацій для маркування вогнепальної зброї та їх основних компонентів;

- Директива 2019/69 від 16 січня 2019 року щодо встановлення технічних умов тривожної та сигнальної зброї;

- Регламент 258/2012 Свропарламенту та Ради СС від 14 травня 2012 року щодо імплементації ст. 10 Протоколу проти незаконного виготовлення та обігу.

Ураховуючи те, що на сьогоднішній день в Україні відсутні первинні законодавчі акти, які регулюють цивільний обіг зброї, а відповідні правові норми регулюються переважно на відомчому нормативному рівні, при підготовці проєктів нормативно-правових актів та законопроєктів, направлених на правове регулювання обігу зброї, доцільно застосовувати європейський досвід із метою імплементації зобов' язань України за Угодою про асоціацію між Україною та СС.

Аналіз останніх досліджень і публікацій. Окремі теоретичні та практичні аспекти гармонізації українського національного права і права СС були предметом дослідження багатьох вітчизняних учених, серед яких В. Д. Малков, В. П. Тихий, В. І. Рибачук, О. М. Сарнавський, М. М. Майстренко, О. С. Клименко, Н. С. Міняйло, В. Л. Соколовський та інші автори $[1 ; 2 ; 11 ; 12]$. Водночас, попри наукові розробки, питання гармонізації українського законодавства у сфері контролю за обігом зброї з правом СС не знайшли комплексного наукового аналізу.

Формування цілей. Метою статті є проведення порівняльного аналізу положень українського та європейського законодавств, які стосуються правового регулювання обігу зброї та формулювання найкращих рішень гармонізації українського національного законодавства у сфері контролю над стрілецькою зброєю та легким озброєнням відповідно до права Свропейського Союзу.

Виклад основного матеріалу. Відсутність дієвого правового врегулювання обігу зброї в Україні є однією з причин збільшення кількості незаконної вогнепальної зброї в державі, що створює потенційні ризики також для сусідніх країн, у тому числі країн-членів СС.

3 метою протидії незаконному обігу зброї, боєприпасів та вибухових речовин на території України та запобігання їх переміщенню через кордон, міжнародними та регіональними організаціями (Організацією Об'єднаних Націй, Організацією з безпеки і співробітництва в Європі, Регіональною Радою 
зі співробітництва тощо) регулярно створюються проєкти, спрямовані на підтримку роботи підрозділів Державної прикордонної служби України, Національної поліції України, Державної митної служби та інших служб, що вказує на серйозну стурбованість міжнародної спільноти проблемами збільшення кількості незаконної зброї в Україні.

Окрім того, з метою зменшення кількості незаконної вогнепальної зброї в країнах Південно-Східної та Східної Європи та запобігання ії розповсюдженню, створено Інформаційний центр Південно-Східної та Східної Європи для контролю за стрілецькою зброєю і легкими озброєннями (далі - SEESAC), який функціонує відповідно до мандату, наданого йому Програмою розвитку Організації Об'єднаних Націй та Регіональною Радою зі співробітництва, діяльність якого направлена на зміцнення безпеки і стабільності в ПівденноСхідній Європі.

У межах своїх повноважень SEESAC регулярно організовує проведення регіональних семінарів із питань гармонізації законодавства у сфері контролю над стрілецькою зброєю та легким озброєнням відповідно до права Європейського Союзу. Постійними учасниками таких семінарів є представники потенційних країн-кандидатів на вступ до ЄС, як-от: Албанія, Сербія, Чорногорія, Македонія, Косово, Молдова та Україна. Під час семінарів обговорюються найкращі рішення та практики адаптації національного законодавства до директив, регламентів та інших правових актів Європейського Союзу, які стосуються сфери контролю над легким озброєнням, стрілецькою зброєю та вибуховими речовинами, стандартизації відповідних положень та процедур. За результатами проведення зазначених заходів для потенційних країн-кандидатів на вступ до ЄС створюються дорожні карти щодо гармонізації національного законодавства з нормативно-правовою базою $Є С$.

Законодавче врегулювання сфери контролю над легким озброєнням та стрілецькою зброєю в ЄС здійснюється директивами, регламентами та іншими правовими актами $€ С$.

Директиви ЄС є правовими інструментами прямої дії, які реалізуються через національне законодавство. Положення директив ЄС є обов' язковими для імплементації в національне законодавство країн-членів СС та країн-кандидатів на вступ до ЄС.

Основним законодавчим актом $Є С$ у сфері обігу цивільної зброї $\epsilon$ Директива 91/477€ЕС щодо контролю за придбанням зброї і володінням зброєю (змінена директивами Європарламенту та Ради ЄС 2008/51/ЄС від 21 травня 2008 року та 2017/852 від 17.05.2017). Зазначена директива регламентує порядок придбання, зберігання, перевезення та інші особливості обігу вогнепальної зброї, а також містить перелік категорій зброї, обіг яких є обмеженим або забороненим для цивільного населення.

Країни-члени ЄС та країни-кандидати на вступ до ЄС зобов'язані у встановлений період гармонізувати своє національне законодавство у відповідності до вимог Директиви 91/477ЄЕС. Окрім того, згідно зі статтею 3 Директиви 91/477€ЕС, країни-члени ЄС можуть прийняти у своєму національному законодавстві положення, які є більш суворими, аніж ті, які передбачені зазначеною Директивою [5]. 
Відповідно до положень Директиви 91/477СЕС, забороненою до цивільного обігу є стрілецька вогнепальна зброя категорії А: автоматична зброя; зброя замаскована під інші предмети; напівавтоматична зброя, перероблена 3 автоматичної; короткоствольна напівавтоматична зброя 3 ємністю магазину понад 20 патронів; довгоствольна напівавтоматична зброя 3 ємністю магазину понад 10 патронів; довгоствольна напівавтоматична зброя яка дозволяє проводити постріли зі складеним прикладом при загальній довжині в такому положенні менше 60 см; будь-яка з вищевказаних видів зброї, перероблена для стрільби холостими, сигнальними або газовими патронами, тощо [5].

Відповідно до статті 6 зазначеної Директиви, країни-члени СС повинні вжити необхідні заходи для заборони придбання та володіння боєприпасами та вогнепальною зброєю категорії А. Для цивільного населення допускається надання дозволу на придбання та володіння тільки напівавтоматичною зброєю категорії А (у тому числі й переробленою з автоматичної) лише з метою спортивної стрільби по мішенях, при цьому спортсмен має надати необхідний перелік документів, що підтверджує його членство в офіційному спортивному стрілецькому клубі та активну участь у проведенні спортивних змагань зі стрільби [5].

Для окремих уповноважених категорій громадян країн-членів СС може бути дозволена зброя категорії В: довгоствольна напівавтоматична зброя 3 ємністю магазину від 3 патронів та короткоствольна зброя, окрім зброї, віднесеної до категорії А [5].

Дозволеною до цивільного обігу в країнах-членах СС, є зброя категорії С, яка підлягає обов'язковому декларуванню: довгоствольна зброя (з довжиною ствола понад $30 \mathrm{~cm}$ або загальною довжиною понад $60 \mathrm{~cm}$ ) та однозарядна короткоствольна зброя (загальною довжиною понад 28 см), окрім зброї, віднесеної до категорій А або В [5].

На сьогодні в Україні відсутні первинні законодавчі акти, що регулюють цивільний обіг зброї, натомість відповідні правові норми коригують підзаконні акти та відомчі інструкції, зокрема Інструкція про порядок виготовлення, придбання, зберігання, обліку, перевезення та використання вогнепальної, пневматичної і холодної зброї, пристроїв вітчизняного виробництва для відстрілу патронів, споряджених гумовими чи аналогічними за своїми властивостями метальними снарядами несмертельної дії, та зазначених патронів, а також боєприпасів до зброї та вибухових матеріалів, затверджена наказом МВС України № 622 від 21.08.1998 [8].

Відповідно до положень діючих нормативних документів, у власності громадян України можуть перебувати наступні категорії стрілецької вогнепальної зброї: довгоствольна гладкоствольна мисливська зброя; довгоствольна нарізна мисливська зброя; нарізна та гладкоствольна спортивна зброя (у тому числі короткоствольна), яка може зберігатися лише в межах стрілецьких тирів і стрільбищ без права зберігання за місцем проживання. Також для окремих категорій громадян може бути дозволена короткоствольна гладкоствольна зброя самозахисту (пристрої для стрільби гумовими чи аналогічними за своїми властивостями снарядами) та нагородна короткоствольна нарізна зброя (у тому числі, бойова). 
Не може перебувати у власності громадян України стрілецька вогнепальна зброя військового призначення та зброя невійськового призначення (окрім зазначених вище категорій), а також вогнепальна зброя, яка призначена для виконання як військових, так і невійськових завдань (багатоцільова зброя).

Таким чином, з формальної точки зору, існуюче українське законодавство у сфері обігу цивільної зброї є більш жорстким, аніж європейське, адже дозволеною для всіх категорій громадян України, які досягли певного віку та не мають судимості й медичних протипоказань, є лише довгоствольна мисливська зброя.

Однак на практищі все виглядає зовсім інакше, адже діючі нормативні документи, що регламентують обіг зброї в державі, не містять чітких критеріїв розмежування мисливської вогнепальної зброї від інших категорій зброї, що створює передумови для реалізації на території України забороненої в країнахчленах ЄС зброї під виглядом мисливської. Окрім того, відсутність дієвого правового врегулювання обігу зброї в державі створює сприятливі умови для корупііі.

Нині Верховною Радою України ведеться активна законотворча робота, направлена на правове врегулювання обігу зброї в Украӥні, зокрема на офіційному вебпорталі Верховної Ради України опубліковано два законопроекти «Про обіг зброї» від 02.09.2019 р. № 1222 та від 20.09 .2019 р. № 1222-1. За результатами порівняльного аналізу положень українського та європейського законодавств, а також положень вищевказаних законопроєктів, установлено, що вони принципово різняться. Результати порівняльного дослідження положень зазначених документів, які стосуються обігу окремих категорій зброї, наведені в Таблиці 1.

Таблиияя 1

Порівняльний аналіз положень українського та європейського законодавств у сфері контролю над легким озброєнням та стрілецькою зброєю, а також положень законопроєктів «Про обіг зброї» від 02.09.2019 № 1222 та від 20.09.2019 № 1222-1, опублікованих на офіційному вебпорталі Верховної Ради України

\begin{tabular}{|c|c|c|c|c|c|}
\hline $\begin{array}{l}3 \\
/ \\
\Pi\end{array}$ & $\begin{array}{l}\text { Категорії } \\
\text { стрілецької зброї } \\
\text { та легкого } \\
\text { озброєння (далі - } \\
\text { SALW) }\end{array}$ & $\begin{array}{l}\text { Положення } \\
\text { Директиви } \\
\text { 91/477€EC, } \\
\text { щодо } \\
\text { щивільного } \\
\text { обігу } \\
\text { вказаної } \\
\text { категорії } \\
\text { SALW }\end{array}$ & \begin{tabular}{|l} 
Положення \\
діючих в Україні \\
правових актів \\
щодо цивільного \\
обігу вказаної \\
категорії SALW
\end{tabular} & $\begin{array}{l}\text { Положення } \\
\text { законопроекту } \\
\text { «Про обіг зброї» } \\
\text { від 02.09.2019 } \\
\text { № } 1222 \text { щодо } \\
\text { цивільного } \\
\text { обігу вказаної } \\
\text { категорії SALW }\end{array}$ & \begin{tabular}{|l|} 
Положення \\
законопроекту \\
«Про обіг \\
3брої» від \\
20.09.2019 \\
№ 1222-1 щодо \\
щивільного \\
обігу вказаної \\
категорії \\
SALW
\end{tabular} \\
\hline & $\begin{array}{l}\text { Автоматична } \\
\text { вогнепальна } \\
\text { зброя }\end{array}$ & Заборонено & Заборонено & Заборонено & $\begin{array}{l}\text { Дозволено } \\
\text { пише } \\
\text { юридичним } \\
\text { особам, } \\
\text { діяльність яких } \\
\text { пов'язана із } \\
\text { функціонуванн } \\
\text { ям тирів та } \\
\text { стрільбищ }\end{array}$ \\
\hline & $\begin{array}{l}\text { Вогнепальна } \\
\text { 3броя }\end{array}$ & Заборонено & Заборонено & Заборонено & Заборонено \\
\hline
\end{tabular}




\begin{tabular}{|c|c|c|c|c|}
\hline $\begin{array}{l}\text { замаскована під } \\
\text { інші предмети }\end{array}$ & & & & \\
\hline $\begin{array}{l}\text { Напівавтоматичн } \\
\text { а вогнепальна } \\
\text { зброя, } \\
\text { перероблена з } \\
\text { автоматичної }\end{array}$ & $\begin{array}{l}\text { Заборонено } \\
\text { (окрім } \\
\text { спортсменів- } \\
\text { членів } \\
\text { офіційних } \\
\text { спортивних } \\
\text { стрілецьких } \\
\text { клубів) } \\
\end{array}$ & $\begin{array}{l}\text { Заборонено } \\
\text { (окрім нарізної } \\
\text { мисливської зброї } \\
\text { виготовленої } \\
\text { промисловим } \\
\text { способом) }\end{array}$ & Дозволено & Дозволено \\
\hline $\begin{array}{l}\text { Короткоствольна } \\
\text { зброя з ємністю } \\
\text { магазину понад } \\
20 \text { патронів }\end{array}$ & $\begin{array}{l}\text { Заборонено } \\
\text { (окрім } \\
\text { спортсменів- } \\
\text { членів } \\
\text { офіційних } \\
\text { спортивних } \\
\text { стрілецьких } \\
\text { клубів) }\end{array}$ & $\begin{array}{l}\text { Заборонено } \\
\text { (окрім } \\
\text { спортивної зброї } 3 \\
\text { можливістю } \\
\text { користування та } \\
\text { зберігання лише } \\
\text { в межах } \\
\text { стрілецьких } \\
\text { тирів) }\end{array}$ & Дозволено & $\begin{array}{l}\text { Дозволено } \\
\text { пише для } \\
\text { спортсменів } 3 \\
\text { можливістю } \\
\text { користування } \\
\text { га зберігання } \\
\text { пише в межах } \\
\text { стрілецьких } \\
\text { тирів }\end{array}$ \\
\hline $\begin{array}{l}\text { Довгоствольна } \\
\text { напівавтоматична } \\
\text { зброя з ємністю } \\
\text { магазину понад } \\
10 \text { патронів }\end{array}$ & $\begin{array}{l}\text { Заборонено } \\
\text { (окрім } \\
\text { спортсменів- } \\
\text { членів } \\
\text { офіційних } \\
\text { спортивних } \\
\text { стрілецьких } \\
\text { клубів) } \\
\end{array}$ & Заборонено & Дозволено & Дозволено \\
\hline $\begin{array}{l}\text { Довгоствольна } \\
\text { напівавтоматична } \\
\text { зброя яка } \\
\text { дозволяє } \\
\text { проводити } \\
\text { постріли зі } \\
\text { складеним } \\
\text { прикладом при } \\
\text { загальній } \\
\text { довжині в такому } \\
\text { положенні менше } \\
60 \text { см }\end{array}$ & $\begin{array}{l}\text { Заборонено } \\
\text { (окрім } \\
\text { спортсменів- } \\
\text { членів } \\
\text { офіційних } \\
\text { спортивних } \\
\text { стрілецьких } \\
\text { клубів) }\end{array}$ & Заборонено & Дозволено & Дозволено \\
\hline \begin{tabular}{|l} 
Довгоствольна \\
напівавтоматичн \\
а зброя \\
(з довжиною \\
ствола понад 30 \\
см або загальною \\
довжиною понад \\
60 см), окрім зброї \\
вказаної вище
\end{tabular} & $\begin{array}{l}\text { Дозволено } \\
\text { пише } \\
\text { пля окремих } \\
\text { пповноважен } \\
\text { их категорій } \\
\text { громадян }\end{array}$ & $\begin{array}{l}\text { Заборонено } \\
\text { (окрім } \\
\text { мисливської зброї } \\
\text { (з довжиною } \\
\text { ствола понад } 20 \\
\text { см та загальною } \\
\text { довжиною понад } \\
80 \text { см), а також } \\
\text { спортивної зброї } 3 \\
\text { можливістю } \\
\text { користування та } \\
\text { зберігання лише } \\
\text { в межах } \\
\text { стрілецьких } \\
\text { тирів) }\end{array}$ & Дозволено & Дозволено \\
\hline
\end{tabular}




\begin{tabular}{|c|c|c|c|c|c|}
\hline & $\begin{array}{l}\text { Короткоствольна } \\
\text { вогнепальна } \\
\text { зброя, окрім зброї } \\
\text { вказаної вище }\end{array}$ & $\begin{array}{l}\text { Дозволено } \\
\text { пише для } \\
\text { окремих } \\
\text { уповноважен } \\
\text { их категорій } \\
\text { громадян }\end{array}$ & $\begin{array}{l}\text { Заборонено } \\
\text { (окрім спортивної } \\
\text { зброї } 3 \\
\text { можливістю } \\
\text { користування та } \\
\text { зберігання лише } \\
\text { в межах } \\
\text { стрілецьких } \\
\text { тирів) }\end{array}$ & Дозволено & $\begin{array}{l}\text { Дозволено } \\
\text { пише для } \\
\text { спортсменів } 3 \\
\text { можливістю } \\
\text { користування } \\
\text { га зберігання } \\
\text { пише в межах } \\
\text { трілецьких } \\
\text { гирів }\end{array}$ \\
\hline & $\begin{array}{l}\text { Довгоствольна } \\
\text { вогнепальна } \\
\text { зброя (3 } \\
\text { довжиною ствола } \\
\text { понад } 30 \text { см або } \\
\text { загальною } \\
\text { довжиною понад } \\
60 \text { см), окрім } \\
\text { зброї, вказаної } \\
\text { вище }\end{array}$ & Дозволено & $\begin{array}{l}\text { Дозволена лише } \\
\text { гладкоствольна та } \\
\text { нарізна } \\
\text { мисливська } \\
\text { зброя, а також } \\
\text { спортивна зброя } 3 \\
\text { можливістю } \\
\text { користування та } \\
\text { зберігання лише } \\
\text { в межах } \\
\text { стрілецьких тирів }\end{array}$ & Дозволено & Дозволено \\
\hline 0 & $\begin{array}{l}\text { Однозарядна } \\
\text { короткоствольна } \\
\text { зброя (загальною } \\
\text { довжиною понад } \\
28 \text { см), окрім } \\
\text { зброї, вказаної } \\
\text { вище }\end{array}$ & Дозволено & $\begin{array}{l}\text { Заборонено } \\
\text { (окрім спортивної } \\
\text { зброї } 3 \\
\text { можливістю } \\
\text { користування та } \\
\text { зберігання лише } \\
\text { в межах } \\
\text { стрілецьких } \\
\text { тирів) }\end{array}$ & Дозволено & $\begin{array}{l}\text { Дозволено } \\
\text { пише для } \\
\text { спортсменів } 3 \\
\text { можливістю } \\
\text { користування } \\
\text { га зберігання } \\
\text { пише в межах } \\
\text { стрілецьких } \\
\text { тирів }\end{array}$ \\
\hline
\end{tabular}

Таким чином, незважаючи на загальноєвропейську практику поступового посилення обмежень у сфері обігу легкого та стрілецького озброєння в країнахчленах СC, обидва вищевказані національні законопроєкти направлені на лібералізацію існуючих обмежень щодо обігу вогнепальної зброї в Україні та розроблені без урахування положень директив, регламентів та інших правових актів ЄС, які стосуються сфери контролю над легким озброєнням та стрілецькою зброєю.

На думку автора, при підготовці національних проєктів нормативноправових актів та законопроєктів в Україні, доцільно використовувати досвід країн, які перебувають на більш пізній стадії інтеграції до СС (Албанія, Сербія, Чорногорія, Македонія, Косово тощо), та які вже імплементували у своє національне законодавство правові акти ЕС.

Висновки. Відсутність дієвого правового врегулювання обігу зброї в Україні створює сприятливі умови для розповсюдження незаконної вогнепальної зброї, що є потенщійною загрозою як для нашої держави, так і для сусідніх країн, у тому числі країн-членів ЄС. Отже, на сьогоднішній день розробка та реалізація законопроєктів, направлених на правове регулювання обігу зброї, є одним із найбільш пріоритетних завдань законодавчої влади України. Ураховуючи положення Конституції України щодо стратегічного курсу держави на набуття повноправного членства в ЄС, при розробці проєктів законодавчих і нормативно-правових актів, які стосуються обігу стрілецької зброї та легкого озброєння, обов'язковим є дотримання вимог 
законодавчих актів і програмних документів з питань адаптації законодавства України до законодавства Свропейського Союзу.

\section{Використані джерела:}

1. Бондар В. С. Письменський Є. О. Зброя та бойові припаси як предмет складу злочину. Актуальні проблеми кримінально-правової охорони громадської безпеки. Харків, 2018. Науково-дослідний інститут вивчення проблем злочинності імені академіка В. В. Сташиса Національної академії правових наук України. С. 112-118.

2. Директива 2019/68 від 16 січня 2019 року щодо встановлення технічних специфікацій для маркування вогнепальної зброї та їх основних компонентів. URL: https:/ / eur-lex.europa.eu/legal-content/ (дата звернення: 25.12.2019).

3. Директива 2019/69 від 16 січня 2019 року щодо встановлення технічних умов тривожної та сигнальної зброї. https:/ / eur- lex.europa.eu/legal- content/EN/TXT/?uri= CELEX\%3A32019 L0069 (дата звернення: 25.12.2019).

4. Директива 91/477€ЕС щодо контролю за придбанням зброї і володінням зброєю (змінена директивами Європарламенту та Ради СС 2008/51/ЄС від 21 травня 2008 року та 2017/852 від 17.05.2017). URL: https://eur-lex.europa.eu/legalcontent/en/ALL (дата звернення: 25.12.2019).

5. Законопроект «Про обіг зброї» №1222 від 02.09.2019. URL: https:/ / w1.c1.rada.gov.ua/pls/zweb2 (дата звернення: 25.12.2019).

6. Законопроект «Про обіг зброї» № 1222-1 від 20.09.2019/ URL: https:/ / w1.c1.rada. gov.ua/pls/zweb2/webproc4 (дата звернення: 25.12.2019).

7. Інструкція про порядок виготовлення, придбання, зберігання, обліку, перевезення та використання вогнепальної, пневматичної і холодної зброї, пристроїв вітчизняного виробництва для відстрілу патронів, споряджених гумовими чи аналогічними за своїми властивостями метальними снарядами несмертельної дії, та зазначених патронів, а також боєприпасів до зброї та вибухових матеріалів, затверджена наказом МВС України від 21.08.1998 № 622. URL: https:/ / zakon2. rada.gov.ua/laws/show / z0637-98/conv/print (дата звернення: 25.12.2019).

8. Регламент 258/2012 Європарламенту та Ради ЄС від 14 травня 2012 року щодо імплементації статті 10 Протоколу проти незаконного виготовлення та обігу. URL: https:/ / eur-lex.europa.eu/legal-content (дата звернення: 25.12.2019).

9. Регламент Комісії СС 2015/2403 від 15 грудня 2015 року щодо встановлення загальних вказівок щодо стандартів та методів деактивації для забезпечення незворотності повторної активації вогнепальної зброї. URL: https://eurlex.europa.eu/legal-content (дата звернення: 25.12.2019).

10. Розслідування злочинів, що вчиняються у сфері обігу вогнепальної зброї та боєприпасів: навч.-практ. посіб. / [Б. І. Бараненко, В.С. Бондар, О. В. Бочковий, М. В. Кривонос та ін.]; за заг. ред. д-ра юрид. наук, проф. В. М. Комарницького; Луган. держ. ун-т внутр. справ ім. Е.О.Дідоренка. Сєвєродонецьк: РВВ ЛДУВС ім. Е. О. Дідоренка, 2019. 799 с.

\section{References:}

1. Bondar, V. S. Pysmenskyi, Ye. O. (2018) Zbroia ta boiovi prypasy yak predmet skladu zlochynu. Aktualni problemy kryminalno-pravovoi okhorony hromadskoi bezpeky. Kharkiv: Naukovo-doslidnyi instytut vyvchennia problem zlochynnosti imeni akademika V. V. Stashysa Natsionalnoi akademii pravovykh nauk Ukrainy, 112-118. [in Ukrainian]. 
2. Dyrektyva 2019/68 vid 16 sichnia 2019 roku shchodo vstanovlennia tekhnichnykh spetsyfikatsii dlia markuvannia vohnepalnoi zbroi ta yikh osnovnykh komponentiv. (2019) URL: https:/ / eur-lex.europa.eu/legal-content/EN/TXT. [in Ukrainian].

3. Dyrektyva 2019/69 vid 16 sichnia 2019 roku shchodo vstanovlennia tekhnichnykh umov tryvozhnoi ta syhnalnoi zbroi. URL: https://eur-lex.europa.eu/legalcontent/EN/TXT/?uri=CELEX. [in Ukrainian].

4. Dyrektyva 91/477YeES shchodo kontroliu za prydbanniam zbroi i volodinniam zbroieiu (zminena dyrektyvamy Yevroparlamentu ta Rady YeS 2008/51/YeS vid 21 travnia 2008 roku ta 2017/852 vid 17.05.2017). URL: https://eur-lex.europa.eu/legalcontent/en/ALL. [in Ukrainian].

5. Zakonoproekt «Pro obih zbroi» 1222 vid 02.09.2019. URL: https://w1.c1.rada.gov.ua/pls/zweb2 /webproc4_1? pf 3511=66594. [in Ukrainian].

6. Zakonoproekt «Pro obih zbroi» 1222-1 vid 20.09.2019. URL: https://w1.c1.rada. gov.ua/pls/zweb2/webproc4_1?pf3511=66918. [in Ukrainian].

7. Instruktsiia pro poriadok vyhotovlennia, prydbannia, zberihannia, obliku, perevezennia ta vykorystannia vohnepalnoi, pnevmatychnoi i kholodnoi zbroi, prystroiv vitchyznianoho vyrobnytstva dlia vidstrilu patroniv, sporiadzhenykh humovymy chy analohichnymy za svoimy vlastyvostiamy metalnymy snariadamy nesmertelnoi dii, ta zaznachenykh patroniv, a takozh boieprypasiv do zbroi ta vybukhovykh materialiv, zatverdzhenoi nakazom MVS Ukrainy vid 21.08.1998 №622 URL: https://zakon2. rada.gov.ua/laws/show/z0637-98/conv/print 1448353239969347?lang=en. [in Ukrainian].

8. Rehlament 258/2012 Yevroparlamentu ta Rady YeS vid 14 travnia 2012 roku shchodo implementatsii statti 10 Protokolu proty nezakonnoho vyhotovlennia ta obihu. URL: https://eur-lex.europa.eu/legal-content/EN. [in Ukrainian].

9. Rehlament Komisii YeS 2015/2403 vid 15 hrudnia 2015 roku shchodo vstanovlennia zahalnykh vkazivok shchodo standartiv ta metodiv deaktyvatsii dlia zabezpechennia nezvorotnosti povtornoi aktyvatsii vohnepalnoi zbroi. URL: https:/ / eur-lex.europa.eu/legalcontent/EN/TXT/?uri=uriserv [in Ukrainian].

10. Rozsliduvannia zlochyniv, shcho vchyniaiutsia u sferi obihu vohnepalnoi zbroi ta boieprypasiv: navch.-prakt. posib. (2019) B. I. Baranenko, V. S. Bondar, O. V. Bochkovyi, M. V. Kryvonos (Eds.) et. al. V. M. Komarnytsky (Ed.); Luhan. derzh. un-t vnutr. sprav im. E. O. Didorenko. Sievierodonetsk: RVV LDUVS. [in Ukrainian].

Стаття надійшла до редколегії 18.11.2019

Соколов А. С., заведующий отделом исследования оружия лаборатории исследований, сертификации оружия и учета Государственного научно-исследовательского экспертно-криминалистического центра МВД Украины

(г. Киев, Украина)

\section{ПЕРСПЕКТИВЫ РЕФОРМИРОВАНИЯ УКРАИНСКОГО ЗАКОНОДАТЕЛЬСТВА В СФЕРЕ ОБОРОТА ОРУЖИЯ С УЧЕТОМ ПОЛОЖЕНИЙ ЕВРОПЕЙСКИХ ПРАВОВЫХ АКТОВ}

Учитывая положения Конституции Украины относительно стратегического курса государства на приобретение полноправного членства в Европейском Союзе, в 
статъе рассмотрены основные положения директив, регламентов и других правовых актов Европейского Союза, касающихся сферы контроля над легким вооружением и стрелковым оружием, а также проведен их сравнительный анализ с положениями существующих национальных нормативно-правовых актов, регулирующих сферу оборота гражданского оружия в Украине. Рассмотрены основные требования европейского законодательства по контролю за оборотом оружия, которые являются обязательными для имплементации в национальное законодательство стран-членов и стран-кандидатов на вступление в Европейский Союз. Проведен сравнительный анализ положений украинского и европейского законодательств, касающихся категорий запрещенного оружия и оружия, гражданский цивильный оборот которых ограничен. Рассмотрены основные положения законодательных инициатив Верховной Рады Украины, направленных на правовое регулирование оборота оружия в Украине и проведено сравнение их основных положений с положениями правовых актов Европейского Союза. Предложены улучшенные решения гармонизации украинского национального законодательства в сфере контроля над стрелковым оружием и легким вооружением в соответствии с правом Европейского Союза.

Ключевые слова: Директива ЕС, Регламент ЕС, имплементация, категории оружия, гармонизация законодательства.

Sokolov O.,

Head of the weapons research Department of the research Laboratory, weapons certification and accounting of the State Scientific Research Forensic Center of the Ministry of Internal Affairs of Ukraine

(Kyiv, Ukraine)

\section{PROSPECTS FOR REFORMING UKRAINIAN LEGISLATION IN THE FIELD OF ARMS TRAFFICKING TAKING INTO ACCOUNT THE PROVISIONS OF EUROPEAN LEGAL ACTS}

Taking into account the provisions of the Constitution of Ukraine on the strategic course of the state for full membership in the European Union, the article discusses the main provisions of directives, regulations and other legal acts of the European Union concerning the sphere of control over small arms and small arms and their comparative analysis with comparative analysis regulatory acts regulating the sphere of trafficking in civilian weapons in Ukraine. The problematic aspects of Ukrainian national legislation in the field of trafficking in weapons and their implications for Ukraine and the neighboring countries as well as the EU Member States are investigated. The main requirements of the European legislation on arms control, which are obligatory for implementation in the national legislation of the Member States and candidate countries for accession to the European Union, are considered. The comparative analysis of the provisions of the Ukrainian and European legislation concerning the categories of illicit weapons and weapons whose civil circulation is restricted is conducted. The main provisions of the legislative initiatives of the Verkhovna Rada of Ukraine aimed at the legal regulation of arms trafficking in Ukraine are considered, and their main provisions are compared with those of the legal acts of the European Union. The best solutions are proposed to harmonize Ukrainian national legislation in the field of small arms and light weapons control in accordance with European Union law. The experience of the implementation of the provisions of directives, regulations 
and other legal acts of the European Union in the national legislation of the countries that are at a later stage of EU integration (Albania, Serbia, Montenegro, Macedonia, Kosovo, etc.) is analyzed.

Key words: EU Directive, EU Regulation, implementation, categories of weapons, harmonization of legislation.

DOI: 10.33766/2524-0323.88.157-165

УДК 343.121.5

Д. В. Шилін,

кандидат юридичних наук, доцент, доцент кафедри кримінального процесу

Національного університету

«Одеська юридична академія»

(м. Одеса, Україна)

e-mail: S_D_V@ukr.net

(Dhttps:// orcid.org/0000-0002-8990-3534

\section{ЗАГАЛЬНІ ПИТАННЯ ВИКОРИСТАННЯ ПРЕЮДИЦІЇ В КРИМІНАЛЬНОМУ ПРОВАДЖЕННІ}

Стаття присвячена дослідженню питань, пов'язаних із межами використання преюдиції в кримінальному провадженні, а також визначенню шляхів удосконалення механізму використання преюдищії в кримінальному провадженні та вирішенню спірних ситуацій, які виникають при використанні преюдицій у кримінальному процесі. Розкрито механізм дії преюдицій у кримінальному процесі. Визначено напрями вирішення преюдищіальних колізій при провадженні в кримінальній справі.

Ключові слова: преюдиція, доказування в кримінальному процесі, преюдиціальність, юридичні факти, обов'язковість судових рішень.

Постановка проблеми. Забезпечення функціонування правосуддя є одним із найголовніших пріоритетів сучасної держави. При цьому завантаженість суддів та складність виконання їх повноважень значно обтяжує поставлене завдання. Для полегшення здійснення судочинства 3 метою забезпечення виконання рішень судів з урахуванням положення ч. 2 ст. 13 Закону України «Про судоустрій та статус судів», згідно з якою обов' язковість урахування (преюдиційність) судових рішень для інших судів визначається законом [4], у кримінальному провадженні активно застосовуються преюдиції.

Проте преюдиції, незважаючи на свою основну роль, викликають чимало суперечностей при застосуванні їх під час вирішення справ кримінальної юрисдикції. Саме тому розгляд значення рішень інших судів для суду, який здійснює правосуддя в межах кримінального провадження, являє собою вагомий теоретичний вклад у науку, який у подальшому може набути практичного застосування.

Аналіз останніх досліджень і публікацій. Дослідженню зазначених питань присвячена велика кількість наукових праць вітчизняних та зарубіжних теоретиків, серед яких А. М. Безруков, О. І. Бережний, О. Ю. Гай, Ю. М. Грошевий,

(с) Шилін Д. В., 2019 